\title{
A krónikus kritikus végtagischaemia invazív kezelésének hosszú távú eredményei
}

\author{
Ruzsa Zoltán dr. ${ }^{1,2}$ - Kuti Ferenc dr. ${ }^{2}$ - Berta Balázs dr. ${ }^{1}$ - Tóth Károly dr. ${ }^{2}$ \\ Bánsághi Zoltán dr. ${ }^{2}$ - Vámosi Zoltán dr. ${ }^{2}$ - Hüttl Kálmán dr. ${ }^{1}$
}

\author{
${ }^{1}$ Semmelweis Egyetem, Általános Orvostudományi Kar, Kardiológiai és Vaszkuláris Központ, Budapest \\ ${ }^{2}$ Bács-Kiskun Megyei Kórház, A Szent-Györgyi Egyetem Oktató Kórháza, Invazív Kardiológiai Osztály, \\ Kecskemét
}

\begin{abstract}
Bevezetés és célkitüzés: A sebészi tibialis bypassműtétnek kritikus végtagischaemiában limitált a kivitelezhetősége, míg a percutan angioplastica széles körben elérhető és jó rövid távú eredményei vannak. Regiszterünk célja az volt, hogy kritikus végtagischaemiában a térd alatti angioplastica hosszú távú eredményeit vizsgáljuk. Módszer: Prospektíven dolgoztuk fel 2008-2011-ben kritikus végtagischaemia miatt térd alatti angioplasticán átesett 281 betegünk adatait. A beavatkozás célja az egyeres kiáramlás biztosítása volt ballonos angioplasticával. Stentimplantációt csak akkor végeztünk, ha a ballonos tágítás után jelentős residualis szúkület vagy dissectio maradt vissza. A vizsgálat elsődleges végpontja a klinikai siker (a fájdalom enyhülése, sebgyógyulás, végtagmentés) és a major események előfordulása volt. A major események közzé tartozott a halál, a myocardialis infactus, a major nem tervezett amputáció, a sebészi revascularisatio szükségessége és a major vérzés. Másodlagos végpontok voltak a beavatkozás sikere, proceduralis adatok és az eszközfelhasználás. Vizsgáltuk a beavatkozás sikerének és a diabeteses láb szindrómának a végtagmentésre kifejtett hatását. A major amputáció hosszú távú halálozásra kifejtett hatását is vizsgáltuk. Eredmények: Betegeink átlagéletkora $72,5 \pm 10,6$ év és a vizsgálati periódus átlaga 40,8 $\pm 9,7$ hónap volt. Jó angiográfiás eredményt 255 végtagban $(90,7 \%)$ értünk el egy egyenes, térd alatti artériában. Ballonos angioplasticát $278(98,9 \%)$ betegnél végeztünk, két betegnél $(0,7 \%)$ rotációs atherectomiát és 74 betegnél $(26,3 \%)$ stentimplantációt. Az elsődleges végpontok tekintetében hosszú távú nyomon követés során (klinikai siker) a nyugalmi fájdalom 56,6\%-ban szünt meg, a fekély 73,5\%ban és a gangraena pedis 46,5\%-ban gyógyult be. A hosszú távú végtagmentés 73,5\% volt; 65,8\% diabeteses és 89,6\% nem diabetes láb szindrómában $(\mathrm{p}=0,001)$. A major nemkívánatos események előfordulása a hosszú távú kontroll során $122(43,4 \%)$ volt. A hosszú távú nyomon követés során 57 (20,3\%) beteg hunyt el: 38 (13,5\%) diabeteses és $19(6,8 \%)$ nem diabeteses láb szindróma esetén $(\mathrm{p}=0,932)$. Sikeres intervenció esetén a betegek $72,3 \%$-ában, míg sikertelen intervenció esetén a betegek 84,6\%-ában értünk el végtagmentést $(\mathrm{p}=0,225)$. Következtetés: A térd alatti angioplasticának jó hosszú távú klinikai eredményei vannak, azonban a betegekben a major események előfordulása magas. Diabeteses láb szindrómában magasabb a hosszú távú amputációszám és a mortalitás. Orv. Hetil., 2017, $158(11), 418-425$.
\end{abstract}

Kulcsszavak: kritikus végtagischaemia, percutan angioplastica, térd alatti angioplastica

\section{Long term results after invasive treatment of critical limb ischemia}

Introduction and aim: Surgical tibial bypass for critical limb ischemia is associated with significant morbidity, mortality, and graft failure, whereas percutaneous angioplasty and stenting has promising results. The objective of this study was the investigation of the long term results of below-knee percutaneous angioplasty for restoring straight inline arterial flow in patients with critical limb ischemia. Method: The clinical and angiographic data of 281 consecutive patients with critical limb ischemia treated by PTA between 2008 and 2011 was evaluated in a prospective register. The aim of the revascularization was to achieve a straight inline flow to the wound with balloon angioplasty. Stent implantation was done in the case of recoil and flow limiting dissection. Primary end points were clinical success (relief of resting pain, healing of ulceration, limb survival) and major adverse events (death, myocardial infarction, major unplanned amputation, need for surgical revascularization, or major bleeding). Secondary end points were the angiographic result of the intervention, procedural data and consumption of angioplasty equipment. The impact of diabetic leg syndrome and the result of the angioplasty on the limb salvage was also investigated. We have analysed 
the impact of major amputation on long term mortality. Results: Mean age of patients was $72.5 \pm 10.6$ years and the follow-up period was $40.8 \pm 9.7$ months. Technical success was reached in $255(90.7 \%)$ of the patient's: 255 limbs straight inline flow with good angiographic result was restored to at least one tibial vessel. Balloon angioplasty, stent implantation and rotational atherectomy was performed in 278 (98.9\%), $74(26.3 \%)$ and 2 patients $(0.7 \%)$. From clinical end points the rest pain was ceased in $56.6 \%$, the ulcer and the gangrena was healed in $73.5 \%$ and $46.5 \%$. The long term limb survival was $73.5 \% ; 65.8 \%$ in diabetic and $89.6 \%$ in non-diabetic leg syndrome $(\mathrm{p}=0.001)$. The major adverse events at long-term follow-up occured in $122(43.8 \%)$ patients. Death occured in $57(20.3 \%)$ of the patients during the long-term follow-up: 38 (13.5\%) vs. $19(6.8 \%)$ in diabetic vs. non-diabetic leg subgroup, respectively $(\mathrm{p}=0.932)$. Long-term limb saving occured in $72.3 \%$ vs. $84.6 \%$ of the patients dependening the procedure was successful or unsuccessful $(\mathrm{p}=0.225)$. Conclusion: Below-knee stent angioplasty for critical limb ischemia results in good clinical outcome, but the major adverse event rate is high. Diabetes mellitus is associated with a high rate of mortality and amputation.

Keywords: critical limb ischemia, percutaneous angioplasty, below-knee stent angioplasty

Ruzsa, Z., Kuti, F., Berta, B., Tóth, K., Bánsághi, Z., Vámosi, Z., Hüttl, K. [Long term results after invasive treatment of critical limb ischemia]. Orv. Hetil., 2017, 158(11), 418-425.

(Beérkezett: 2016. december 18.; elfogadva: 2017. január 16.)

\section{Rövidítések}

ASO = atherosclerosis obliterans; $\mathrm{CI}=$ claudicatio intermittens; DEB = (drug-eluting balloon) gyógyszeres ballon; DES = (drug-euting stent) gyógyszeres stent; KVI = kritikus végtagischaemia; MACCE = (major adverse cardiac and cerebrovascular events) major nemkívánatos cardialis és cerebrovascularis események; $\mathrm{MAE}=$ (major adverse events $)$ major nem kívánatos események; PTA = percutan transluminalis angioplastica; $\mathrm{RA}=$ rotációs atherectomia

A kritikus végtagischaemia (KVI) alatt az alsó végtag kritikus keringészavarát értjük, amely klinikailag nyugalmi fájdalom, krónikus lábszárfekély és gangraena pedis képében jelentkezhet. A KVI akkor alakul ki, ha a végtag keringése a distalis perfúziós nyomás csökkenése miatt $(<50 \mathrm{Hgmm})$ romlik, elsősorban térd alatti obliteratív érbetegség következtében [1]. A betegség gyógyítása gyógyszeres vagy invazív úton lehetséges, és az invazív kezelés vagy sebészi revascularisatióval, vagy percutan transluminalis angioplasticával (PTA) kivitelezhetô $[2$, $3]$. Az artériás revascularisatio célja az egyeres kiáramlási pálya biztosítása elsősorban az angiográfiás zónák szerint, amely a véráramlás helyreállításával a nyugalmi fájdalom enyhülését és sebgyógyulást idézi elő $[4,5]$. Prospektív vizsgálatunk célja az volt, hogy KVI-ban a többemeletes és izolált térd alatti PTA-n átesett betegeink adatait feldolgozzuk, a beavakozás hosszú távú klinikai kimenetelét megvizsgáljuk és új irodalmi áttekintést adjunk a KVI kezelését illetően.

\section{Módszer}

\section{Vizsgált betegcsoport}

Prospektíven dolgoztuk fel a 2008-2011-ben KVI miatt térd alatti angioplasticán átesett 281 betegünk adatait regiszterünk alapján. A beavatkozás célja az egyeres kiáramlás biztosítása volt ballonos angioplasticával. Elsődleges és másodlagos végpontokat állítottunk fel, hogy a beavatkozás klinikai kimenetelét vizsgáljuk. A diabeteses láb szindrómás és a major amputált betegek klinikai kimenetelét vizsgáltuk. Az elhunyt betegek klinikai és patológiai leírásából a halál okát követtük nyomon. Alcsoport-analízist is végeztünk: a diabeteses láb szindrómában vizsgáltuk a végtagmentést és a betegek mortalitását.

\section{Elsődleges végpontok}

- Klinikai siker, amely a nyugalmi fájdalom enyhülését, a fekély gyógyulását és a claudicatio javulását foglalta magában.

- Major események (MAE), amelybe beletartozott a halál, a myocardialis infactus, a major nem tervezett amputáció, a sebészi revascularisatio szükségessége és a major vérzés.

\section{Másodlagos végpontok}

A beavatkozás angiográfiás eredménye, proceduralis adatok és az eszközfelhasználás.

\section{Gyógyszeres kezelés}

A betegek a beavatkozás alatt és után $100 \mathrm{mg}$ aszpirint kaptak. Clopidogrelt csak a stentimplantáción átesett betegeknek adtunk (300 mg telítő dózis és $75 \mathrm{mg}$ fenntartó dózis). Az antibiotikum-adás a sebtenyésztés eredménye alapján történt.

\section{A percutan angioplastica technikája}

\section{Behatolás}

A behatolást anterograd, cross over és transpedalis behatolásból végeztük. Az anterograd behatoláshoz 5 F-es 45 


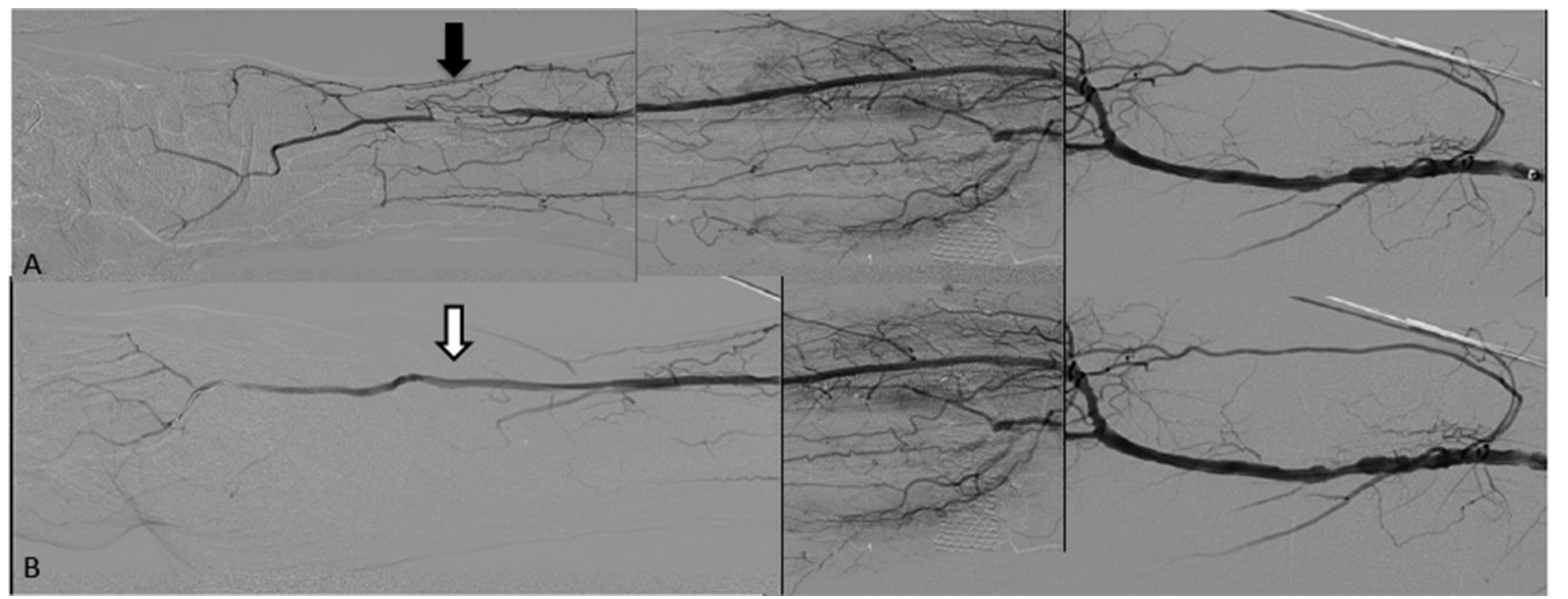

1. ábra

Anterograd angioplastica. A) Angiográfia igazolja a distalis tibialis anterior occlusiót (fekete nyíl). B) Ballonos angioplastica után a záró angiográfia jó áramlást mutat a distalis tibialis anteriorban (fehér nyíl)

cm-es sheathet használtunk (Cordis Co. és Cook Co.), míg cross over behatoláshoz 6 F-es 55-90 cm-es sheathet vezettünk át a contralateralis femoralis artériából az érintett arteria femoralis superficialisba. A transpedalis szúrást [6] röntgenkontroll alatt végeztük egy radialis szúrótü és egy dedikált transpedalis sheath segítségével (Cook Co.).

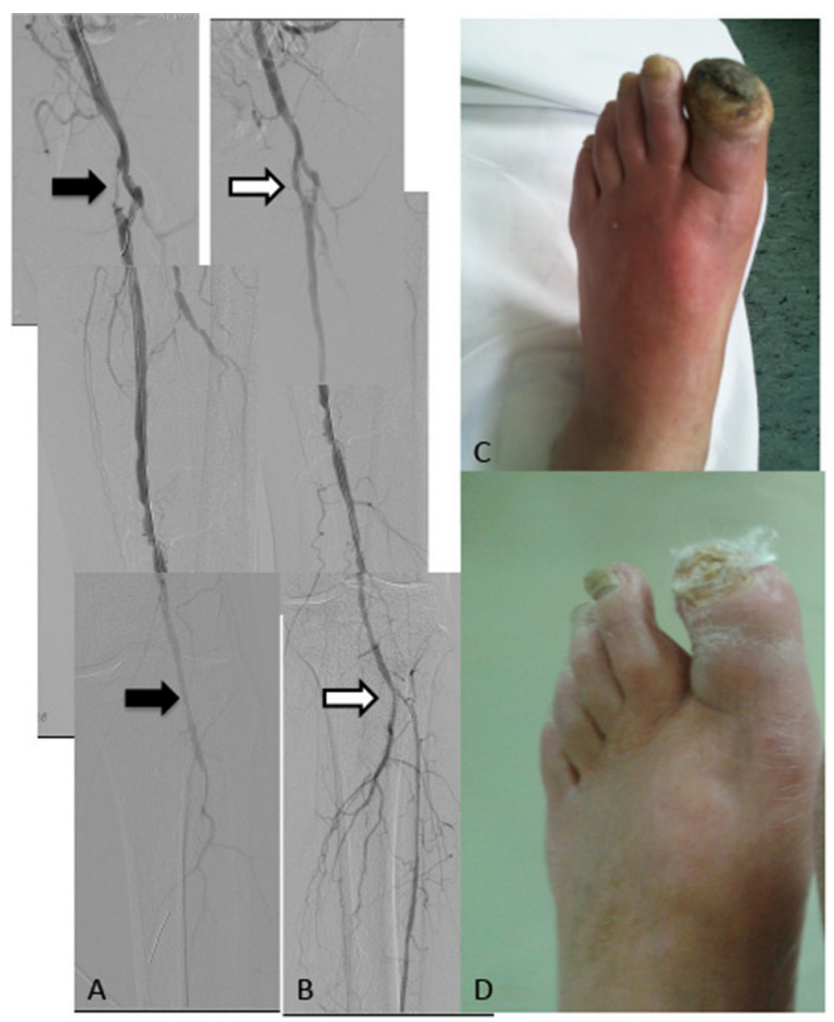

2. ábra

Retrograd angioplastica. A) Angiográfia igazolja a szignifikán eredési arteria femoralis superficialis szúkületet és a distalis térd alatti három ér occlusióját (fekete nyíl). B) Sikertelen anterograd recanalisatio után transpedalis úton megtágított tibialis anterior és arteria femoralis superficialis (fehér nyíl). C) Diabeteses láb intervenció előtt. D) Sikeres intervenció után gyógyult láb

\section{Angioplastica technikája}

A térd alatti szúkületen egy $300 \mathrm{~cm} 0,014$ " (Progress 40 , Abbot) vagy 0,018 " drótot (V18, Boston Sci) vezettünk át, és a szúkületet egy „ower-the-wire” dedikált térd alatti ballonnal tágítottuk (Fox SV - Abbot Co, Amphirion Deep-Invatec-Medtronic Co.). A ballonos tágítás után recoil, occlusiv dissectio és elzáródás esetén első lépésben hosszan tartó ballonos tágítást, majd sikertelenség esetén stentimplantációt végeztünk (1.ábra).

Ha a szúkületen nem tudtunk anterograd átjutni, akkor a beavatkozást retrograd úton végeztük transpedalis behatolásból (2. ábra).

\section{Beteg-nyomonkövetés}

Betegeinket angiológiai vagy érsebészeti ambulancián követtük. Azokat a betegeket, akiket az ambulancián nem tudtunk megvizsgálni, telefonon értük el, és a panaszokról és klinikai státuszról gyújtöttünk információt.

\section{Angiográfiás eredmények és klinikai kimenetel}

Jó angiográfiás eredményü intervenciónak tekintettük a beavatkozást, ha nem maradt vissza 30\%-nál nagyobb residualis szúkület és az áramlás jó volt. Szuboptimális eredménynek tekintettük, ha az áramlás nem volt gyors és 30-50\%-os residualis szúkület maradt visza. Sikertelen angioplasticának tekintettük, ha $50 \%$-nál nagyobb residualis szúkület, occlusiv dissectio maradt vissza és a flow nem javult vagy megszűnt.

Primer klinikai sikernek tekintettük a beavatkozást, ha megszűnt a nyugalmi fájdalom, a fekély vagy a gangraena meggyógyult.

Végtagmentésnek tekintettük, ha a betegnek nem kellett major amputációt végezni.

Major amputáció térd feletti vagy alatti amputációt jelentett, míg minor amputációnak tekintettük a transmetatarsalis vagy ettől distalis amputációt a végtagon. 
1. táblázat | Demográfiai és klinikai adatok

\begin{tabular}{|c|c|c|}
\hline $\begin{array}{l}\text { Demográfiai és klinikai } \\
\text { adatok }\end{array}$ & & $\mathrm{n}=281(\%)$ \\
\hline Demográfiai adatok & $\begin{array}{l}\text { Kor (évek) } \\
\text { Nem: férfi } \\
\text { Hypertensio } \\
\text { Dyslipidaemia } \\
\text { Dohányzás } \\
\text { Diabetes mellitus } \\
\text { Súlyos obesitas }\end{array}$ & $\begin{array}{r}72,5 \pm 10,6 \\
174(61,9 \%) \\
242(86,1 \%) \\
88(31,3 \%) \\
165(58,7 \%) \\
191(68,0 \%) \\
18(6,4 \%)\end{array}$ \\
\hline $\begin{array}{l}\text { Cardialis } \\
\text { és angiológiai } \\
\text { előzmények }\end{array}$ & $\begin{array}{l}\text { Korábbi MI } \\
\text { Korább PCI } \\
\text { Korábbi coronaria- } \\
\text { bypassmútét } \\
\text { Korábbi PTA } \\
\text { Korábbi bypassmútét }\end{array}$ & $\begin{array}{l}25(8,9 \%) \\
11(3,9 \%) \\
16(5,7 \%) \\
50(17,8 \%) \\
18(6,4 \%)\end{array}$ \\
\hline Tünetek & $\begin{array}{l}\text { Ischaemiás fájdalom } \\
\text { Fekély } \\
\text { Gangraena }\end{array}$ & $\begin{array}{r}199(70,8 \%) \\
34(12,1 \%) \\
186(66,2 \%)\end{array}$ \\
\hline $\begin{array}{l}\text { Rutherford- } \\
\text { klasszifikáció }\end{array}$ & $\begin{array}{l}\text { I1 } \\
\text { I2 } \\
\text { I3 } \\
\text { II4 } \\
\text { III5 } \\
\text { III6 }\end{array}$ & $\begin{aligned} & 0 \\
& 0 \\
& 0 \\
& 50(17,8 \%) \\
& 208(74,0 \%) \\
& 23(8,2 \%)\end{aligned}$ \\
\hline
\end{tabular}

$\mathrm{MI}=$ myocardialis infarctus; $\mathrm{PCI}=$ percutan coronariaintervenció; PTA $=$ percutan transluminalis angioplastica

Major nemkinánatos események (major adverse events - MAE): teljes halálozás, a sürgős sebészi beavatkozás, beleértve az amputációt is, myocardialis infarctus, urgens rePTA.

Major nemkinánatos cardialis és cerebrovascularis események (major adverse cardiac and cerebrovascular events - MACCE): teljes halálozás, stroke, myocardialis infarctus és percutan coronariaintervenció és bypassmútét.

A behatolási szövődményekből major vascularis szövődménynek tekintettük azt a vascularis vérzéses komplikációt, ha a vérhemoglobin $32 \mathrm{~g} / \mathrm{l}$-nél alacsonyabb volt, transzfúziót kellett adni, sebészi korrekció vált szükségessé vagy ha a beteg vascularis szövődménye miatt hosszabb hospitalizáció lett volna szükséges. Minor vascularis szövődményről beszéltünk, ha a vérzés haematomaképződésben nyilvánult meg és nem igényelt speciális kezelést.

\section{Statisztikai analizis}

A folyamatos változókat átlag \pm szórás formában adtuk meg. A csoporton belüli összefüggések értékeléséhez kétmintás t-próbát használtunk. Az adatok statisztikai értékelését paraméteres tesztekkel, a túlélési görbéket Kaplan-Meier-analízissel, összehasonlításukat log-rank teszttel végeztük. Minden statisztikai számításhoz a Statistica 8.0 (StatSoft Inc, Tulsa, OK, Amerikai Egyesült Államok) számítógépes szoftvercsomagot használtuk. Statisztikailag szignifikánsnak tekintettük a p 0,05 alatti értéket.
2. táblázat |Angiográfiás és intervenciós adatok

\begin{tabular}{lc}
\hline Angiográfiás és intervenciós adatok & $\mathrm{n}=281(\%)$ \\
\hline Tágitott evek & \\
Arteria iliaca & $0(0)$ \\
Arteria femoralis communis & $0(0)$ \\
Arteria femoralis superficialis & $65(23,1)$ \\
Arteria poplitea & $73(26)$ \\
Arteria tibialis anterior & $186(66,2)$ \\
Arteria peronea & $49(17,4)$ \\
Arteria tibialis posterior & $53(18,9)$ \\
Truncus tibiofibularis & $6(2,1)$ \\
Arteria dorsalis pedis & $4(1,4)$ \\
Arteria plantaris & $1(0,3)$ \\
\hline Kvantitatív angiográfia & \\
Diameterstenosis (\%) & 83,23 \\
Laesio hossza (mm) & 205,5 \\
Referenciadiameter (mm) & 3,359 \\
Krónikus elzáródás & 165 \\
\hline PTA-technika & \\
Behatolás & \\
Anterograd & $266(94,7)$ \\
Cross over & $4(1,4)$ \\
Retrograd & $44(15,6)$ \\
Angioplastica módja & \\
Ballonos angioplastica & $270(96,1)$ \\
Stent implantáció & $30(18,1)$ \\
Krónikus elzáródás megnyitása & \\
\hline Az intervenció angiográfiás kimenetele & \\
Sikeres & \\
Sikertelen vagy kielégitö evedményü & \\
\hline & \\
& \\
&
\end{tabular}

PTA $=$ percutan transluminalis angioplastica

3. táblázat | Felhasznált eszközök és anyagok

\begin{tabular}{lc}
\hline Eszközök és felhasznált anyagok & $\mathrm{n}=281(\%)$ \\
\hline Sheath & $300(106,7)$ \\
Guidewire 0,035" & $389(138,4)$ \\
Guidewire 0,018” és 0,014” & $439(156,2)$ \\
Ballon & $499(177,6)$ \\
Stent & $74(26,3)$ \\
- Gyógyszeres stent & $3(1)$ \\
Thrombusaspirációs katéter & $0(0)$ \\
Rotablator & $2(0,7)$ \\
\hline
\end{tabular}

\section{Eredmények}

\section{Demográfiai és klinikai adatok}

Betegeink demográfiai és klinikai adatait az 1. táblázatban foglaltuk össze. Betegeink átlagéletkora 72,5 \pm 10,6 év és a vizsgálati periódus átlaga 40,8 $\pm 9,7$ hónap volt. A vizsgált populációban 199 betegnél $(70,8 \%)$ nyugalmi fájdalom, 34 betegnél $(12,1 \%)$ ulcus cruris és 186 betegnél $(66,2 \%)$ gangraena pedis fordult elő. $191(68,0 \%)$ betegnek volt diabeteses láb szindrómája. 

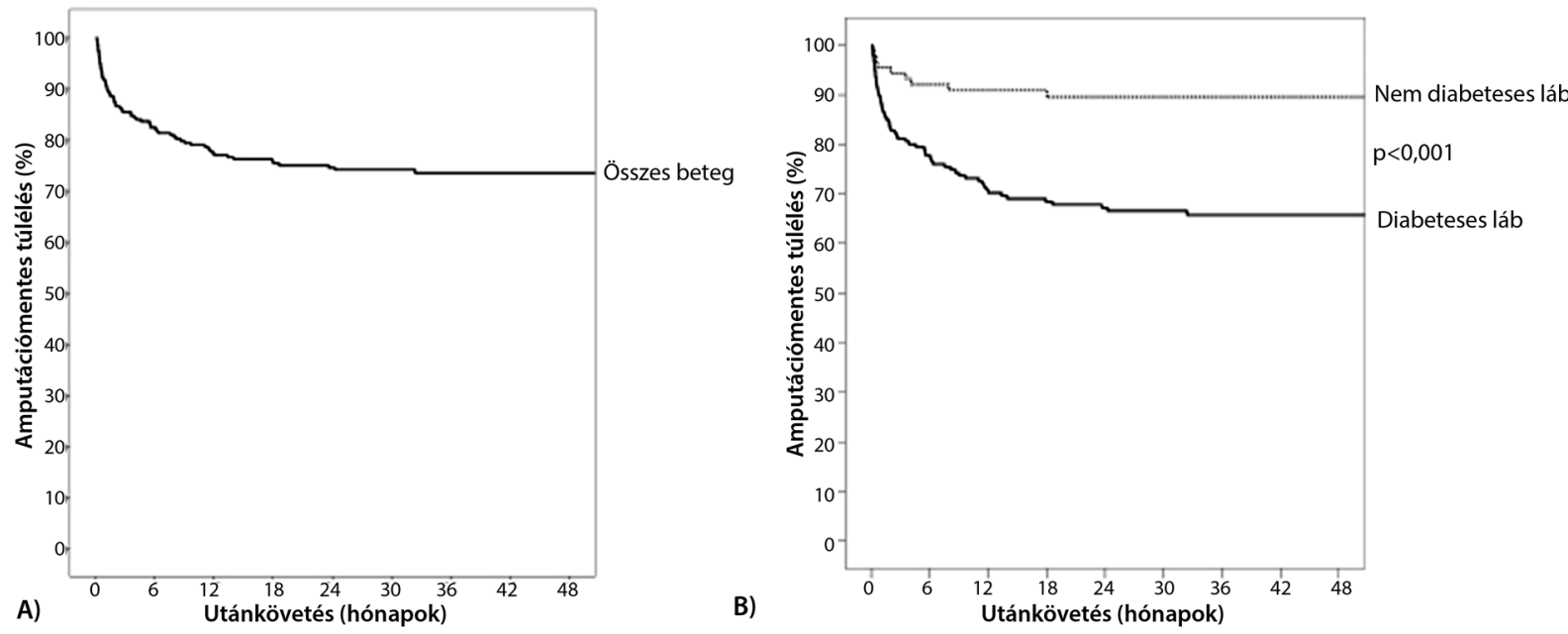

3. ábra | Amputációmentes túlélés. A) Minden beteg. B) Diabeteses és nem diabeteses láb szindróma esetén
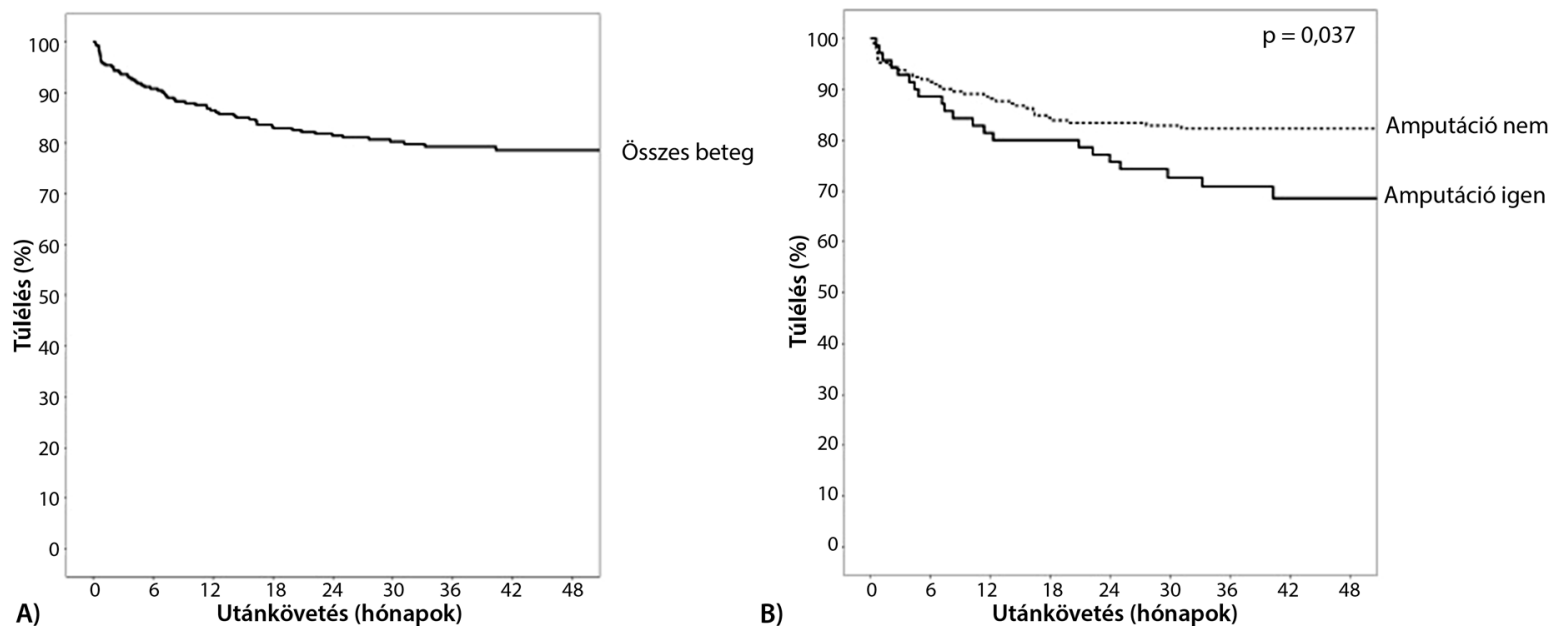

4. ábra | Túlélés. A) Minden beteg. B) Végtagamputált és nem amputált betegek túlélése

\section{Intervenciós adatok}

A betegek angiográfiás és intervenciós adatait a 2. táblázatban összegeztük. Jó angiográfiás eredményt 255 végtagban $(90,7 \%)$ értünk el, legalább egy egyenes, térd alatti artériában. Ballonos angioplasticát 278 betegnél végeztünk, két betegnél rotációs atherectomiát és 74 betegnél stentimplantációt. A felhasznált eszközöket a 3. táblázatban összesítettük.

\section{Klinikai kimenetel}

Az elsődleges végpontok tekintetében hosszú távú nyomon követés során (klinikai siker) azt tapasztaltuk, hogy a nyugalmi fájdalom 56,6\%-ban szűnt meg, a fekély $73,5 \%$-ban és a gangraena pedis $46,5 \%$-ban gyógyult be. Diabeteses láb szindrómában $51,1 \%$-ban tudtunk teljes sebgyógyulást elérni. A hosszú távú kumulatív végtagmentés $73,5 \%$ volt: diabeteses láb szindrómában $65,8 \%$,
4. táblázat | Szövődmények

\begin{tabular}{lll}
\hline Komplikációk & $\begin{array}{l}2 \text { hónapos utánkövetés } \\
\mathrm{n}=281(\%)\end{array}$ & $\begin{array}{l}3 \text { éves utánkövetés } \\
\mathrm{n}=281(\%)\end{array}$ \\
\hline
\end{tabular}

Proximalis nehatolási

komplikációk

Minor vascularis

szövődmény $\quad 6(2,1 \%) \quad 6(2,1 \%)$

Major vascularis

szövődmény $\quad 2(0,7 \%) \quad 2(0,7 \%)$

\begin{tabular}{lcr}
\hline MAE & $55(19,6 \%)$ & $122(43,4 \%)$ \\
$\begin{array}{l}\text { Halál } \\
\text { Reintervenció vagy } \\
\text { bypassmútét }\end{array}$ & $14(5,0 \%)$ & $19(7,2), 3 \%)$ \\
$\begin{array}{l}\text { Major nem tervezett } \\
\text { amputáció }\end{array}$ & $37(13,5 \%)$ & $70(24,9 \%)$ \\
AMI & $3(1,1)$ & $35(12,5 \%)$ \\
\hline
\end{tabular}

$\mathrm{AMI}=$ akut myocardialis infarctus;

$\mathrm{MAE}=$ (major adverse events) major nemkívánatos események 

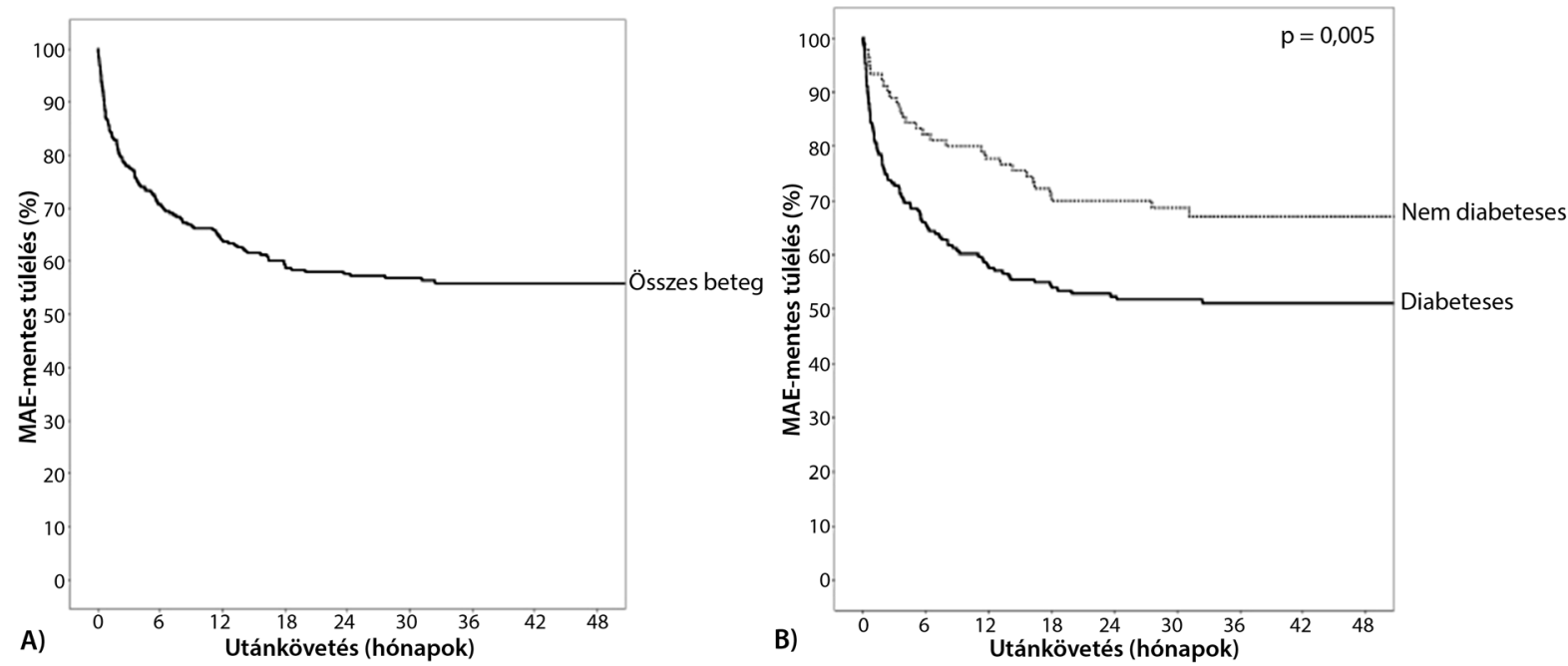

5. ábra $\quad$ MAE-mentes túlélés. A) Minden beteg. B) Diabeteses és nem diabeteses láb szindróma esetén
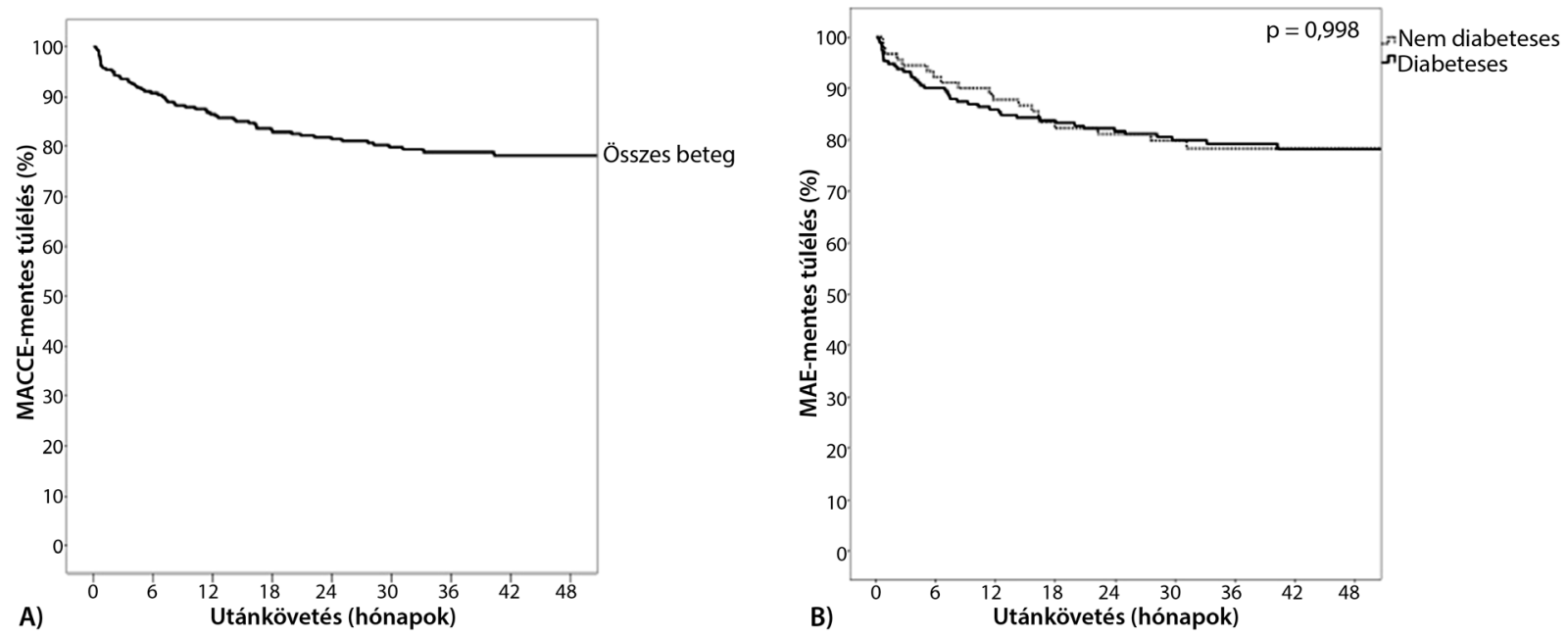

6. ábra $\quad$ MACCE-mentes túlélés. A) Minden beteg. B) Diabeteses és nem diabeteses láb szindróma esetén

nem diabeteses láb szindrómában $89,6 \%(\mathrm{p}=0,001)$ (3. ábra: Amputációmentes túlélés). Technikailag sikeres intervenció esetén a végtagmentés $72,3 \%$ volt, míg sikertelen intervenció esetén $84,6 \%(\mathrm{p}=0,225)$. A betegeink túlélését a 4. ábra foglalja össze.

\section{Szövödmények}

A szövődmények előfordulását az 4. táblázat foglalja össze.

Vascularis szöpödmények tekintetében a vizsgált betegcsoportban hat minor (haematoma) $(2,1 \%)$ és két major (femoralis pseudoaneurysma - trombininjekcióval kezelt) $(0,7 \%)$ fordult elő.

A major események (MAE) elöfordulása két hónapos és hároméves kontroll során $55(19,6 \%)$ és $122(43,4 \%)$ volt (5. ábra-MAE-mentes túlélés). A MAE összetétele két hónapos kontrollnál: 14 halál (5,0\%), három myocar- dialis infarctus $(1,1 \%)$, hét reintervenció $(2,5 \%)$ és 37 major amputáció $(13,4 \%)$; míg a késői MAE: 57 haláleset $(20,7 \%), 10$ myocardialis infarctus $(4,0 \%), 19$ reintervenció $(7,2 \%)$ és 70 major amputáció $(26,5 \%)$. A beavatkozás után 24 betegnél $(8,5 \%)$ kellett kiegészítő tervezett ujj- (minor) amputációt végezni. A végtagamputált betegekben a késối major nemkívánatos cardialis és cerebrovascularis események (MACCE) előfordulása, illetve az összhalálozás szignifikánsan magasabb volt, mint azoknál a betegeknél, akiknél a végtagot sikerült megmenteni: $30,8 \%$ vs. $17,8 \%(\mathrm{p}=0,021)$ és $29,2 \%$ vs. $17,8 \%(\mathrm{p}=0,037)$ (6. ábra-MACCE-mentes túlélés). A vizsgálati periódus során a halál oka kilenc betegnél myocardialis infarctus $(15,5 \%)$, három betegnél stroke $(5,2 \%), 22$ betegnél légzési vagy szívelégtelenség $(37,9 \%)$, kilenc betegnél pneumonia $(15,5 \%)$, nyolc betegnél szepszis $(13,8 \%)$, egyéb ok hét $(12,1 \%)$ esetben volt. 


\section{Megbeszélés}

A perifériás ütőérbetegség vagy más néven atherosclerosis obliterans tünetei a claudicatio intermittens és a KVI (ishaemiás nyugalmi fájdalom, nem gyógyuló fekély és gangraena). KVI esetén az optimalizált gyógyszeres kezelés mellett a végtag artériás ellátását vagy sebészi, vagy percutan úton lehet biztosítani.

A sebészi revascularisatio (tibialis bypass) a gold standard a térd alatti occlusiv érbetegség megoldására, amely tartósságát tekintve a legjobb eljárás, de a betegek nagy része nem alkalmas a mútétre a rossz általános állapot vagy súlyos társbetegség miatt [2, 3]. Másfelől a graftolandó terület gyulladt és fertőzött lehet vagy a kifolyótraktus nagyon rossz, ezért nincs alkalmas hely distalis anastomosis felvarrására. A felvarrható véna hiánya is kizárja a bypassmütétet, mivel a műanyag protézisek nyitva maradása nagyon rossz. Ezen okok miatt napjainkban egyre elfogadottabb, hogy a PTA az elsődleges kezelés, ha a sebészi áthidalás valamely ok miatt nem kivitelezhető.

\section{Angioplastica}

Számos tanulmány igazolta az endovascularis kezelés végtagmentő hatását, és a legnagyobb előnye ennek a technikának a minimálisan invazív jelleg, a kevesebb intézeti tartózkodás és az alacsonyabb mortalitás, illetve morbiditás [4-12]. Tekintetbe véve azt, hogy az intervenció elsődleges célja az amputáció megelőzése és a funkcionális végtag megmentése, a térd alatti PTA elsődlegesen ebból a célból történik. Nagy nemzetközi vizsgálatok adatai szerint jelenleg a térd alatti PTA-val 5681\%-ban lehet végtagmentést elérni [3-8]. Számos tanulmány szerint az angioplastica sikere javította a végtagmentést, de a hosszú távú eredményekről csak kevés tanulmány készült [11-13]. Vizsgálatunk során a cél mindig az angiográfiás zónák követése volt, azonban csak 255 (90,7\%) betegben tudtunk direkt revascularisatiót elérni, mivel sok esetben nem tudtuk a donor artériát megnyitni. Ezekben az esetekben indirekt revascularisatiót végeztünk, amellyel a kollateralis flowt növeltük - az indirekt technikának nincsenek olyan jó eredményei, mint a direkt revascularisatiónak, de összességében a beavatkozás eredményét tovább tudtuk növelni. Iida és mtsai közölték publikációjukban, hogy az angiográfiás zónák szerinti direkt revascularisatio jobb hosszú távú végtagmentést ( $82 \pm 5 \%$ vs. $68 \pm 5 \%, \mathrm{p}=0,01)$ és kevesebb major eseményt eredményezett ( $51 \pm 8 \%$ vs. $28 \pm 8 \%, \mathrm{p}=0,008)$, mint az indirekt revascularisatio. A direkt csoportban a végtag-amputáció független prediktora volt a $\mathrm{HgbA}_{1 \mathrm{c}}$-szint és a cilostasolszedés, míg az indirekt csoportban a CRP-szint [8]. Ferraresi és mtsai izolált térd alatti szúkületek PTA-s eredményeit vizsgálták retrospektíven, és $2,9 \pm 1,4$ év nyomon követésnél 93\%-os végtagmentést és egy év után 43\%-os restenosist találtak [12]. A diabeteses láb szindróma klasszikusan a neuropathia, vasculopathia és az infekció együttes jelen- létét jelenti, de a szakirodalom a súlyos CLI-t vasculopathiával és infekcióval is ide sorolja. A mi vizsgálati csoportunkban a hosszú távú végtagmentés diabeteses láb szindróma esetén $68,1 \%$ volt, míg a teljes végtagmentés $75,1 \%$ volt. A vizsgált populációban a sikeres és a nem sikeres angioplastica között nem volt szignifikáns különbség a végtagmentésben, amely azzal magyarázható, hogy a végtag vérellátásának javítása sokszor nem volt elegendő a végtag megmentéséhez a kiterjedt infekció miatt, illetve a sebészi major amputáció a beavatkozás utáni korai posztoperatív szakában történt.

A PTA-hoz szükséges eszközök fejlődése, mint az új vezetődrótok, a kis profilú ballonok, az endovascularis lézer, rotációs és orbitális atherectomia, javította az intervenció technikai sikerét, de hosszú távú ér-nyitvamaradást csak az új, térd alatti gyógyszeres ballonok (DEB) és gyógyszeres stentek (DES) javították [9-11]. Igaz, ezen eszközök nem javították a konvencionális PTA-hoz képest a hosszú távú végtagmentést, csak a reintervenciók számát csökkentették [9-11]. Vizsgálatunk során még gyógyszeres ballonokat nem, illetve DES-t is csak 1,1\%ban használtunk, viszont a stentimplantáció már 4,1\%-os volt a teljes populációban.

A végtagmentés hosszú távon elsőrendü ezeknek a betegeknek a számára, mivel az immobilitás gyorsítja az atherosclerosist, illetve a betegek sokkal könnyebben kapnak légúti infekciót. Diabeteses láb szindróma esetén a major amputáción átesett betegek hosszú távú mortalitása magasabb volt, mint azoknál a betegeknél, akik nem estek át amputáción. Faglia és mtsai 564 diabeteses beteg vizsgálata során azt találták, hogy a major amputáció összefüggött a revascularisatio sikertelenségével, mindhárom térd alatti ér occlusiójával, a sebfertőzéssel és a $\mathrm{TcPO}_{2}$ emelkedésével a beavatkozás után. A halálozás összefüggött a magas életkorral, a pozitív cardialis anamnézissel, a dialízissel, a csökkent ejekciós faktorral és a revascularisatio sikerével [14]. A különböző vizsgálatokban a halál okát nem vizsgálták. Vizsgálatunk során azt találtuk, hogy a betegek halálozásának oka 37,9\%-ban légzési elégtelenség, 27,6\%-ban pneumonia-szepszis és 15,5\%ban myocardialis infarctus volt, amely alátámasztja azt a tényt, hogy a betegek az immobilizáció szövődményeiben halnak meg.

\section{A vizsgálat limitációi}

A vizsgálat legfőbb limitációja az angiográfiás kontroll hiánya, az, hogy a restenosis előfordulását nem vizsgáltuk, és hogy a vizsgálati periódusban még nem voltak elérhetőek gyógyszeres ballonok és stentek. A vizsgálat során a diabeteses láb szindrómában szenvedő betegnek nem volt neuropathiás vizsgálata.

\section{Következtetés}

A térd alatti angioplasticának jó hosszú távú klinikai eredményei vannak, azonban a betegekben a major ese- 
mények előfordulása magas. Diabeteses láb szindrómában magasabb a hosszú távú amputációs ráta és a mortalitás.

Anyagi támogatás: A közlemény megírása anyagi támogatásban nem részesült.

Szerzői munkamegosztás: R. Z.: A kézirat megírása. K. F., T. K., V. Z.: Adatgyưjtés: R. Z., H. K., B. Z.: Beavatkozások végzése. B. B.: Statisztika. A cikk végleges változatát valamennyi szerző elolvasta és jóváhagyta.

Érdekeltségek: A szerzőknek nincsenek érdekeltségeik.

\section{Irodalom}

[1] Becker, F., Robert-Ebadi, H., Ricco, J. B., et al.: Chapter I: Defini tions, epidemiology, clinical presentation and prognosis. Eur. J. Vasc. Endovasc. Surg., 2011, 42(Suppl. 2), S4-S12.

[2] Bradbury, A. W., Adam, D. J., Bell, J., et al.: Bypass versus Angioplasty in Severe Ischaemia of the Leg (BASIL) trial: An intention-to-treat analysis of amputation-free and overall survival in patients randomized to a bypass surgery-first or a balloon angioplasty-first revascularization strategy. J. Vasc. Surg., 2010, 51(5 Suppl.), 5S-17S.

[3] Holm, J., Arfvidsson, B., Jivegaird, L., et al.: Chronic lower limb ischaemia. A prospective randomised controlled study comparing the one-year results of vascular surgery and percutaneous transluminal angioplasty (PTA). Eur. J. Vasc. Surg., 1991, 5(5), 517-522.

[4] Tsetis, D., Belli, A. M.: The role of infrapopliteal angioplasty. Br. J. Radiol., 2004, 77(924), 1007-1015.

[5] Dorros, G., Jaff, M. R., Dorros, A. M., et al.: Tibioperoneal (outflow lesion) angioplasty can be used as primary treatment in 235 patients with critical limb ischemia: Five-year follow-up. Circulation, 2001, 104(17), 2057-2062.

[6] Ruzsa, Z., Nemes, B., Bánsághi, Z., et al.: Transpedal access after failed anterograde recanalization of complex below-the-knee and femoropoliteal occlusions in critical limb ischemia. Catheter Cardiovasc. Interv., 2014, 83(6), 997-1007.

[7] Söder, H. K., Manninen, H. I., Jaakkola, P., et al.: Prospective trial of infrapopliteal artery balloon angioplasty for critical limb ischemia: angiographic and clinical results. J. Vasc. Interv. Radiol., 2000, 11(8), 1021-1031.

[8] Iida, O., Soga, Y., Hirano, K., et al.: Long-term results of direct and indirect endovascular revascularization based on the angiosome concept in patients with critical limb ischemia presenting with isolated below-the-knee lesions. J. Vasc. Surg., 2012, 55(2), 363-370.e5

[9] Siablis, D., Kitrou, P. M., Spiliopoulos, S., et al.: Paclitaxel-coated balloon angioplasty versus drug-eluting stenting for the treatment of infrapopliteal long-segment arterial occlusive disease: the IDEAS randomized controlled trial. JACC Cardiovasc. Interv., 2014, 7(9), 1048-1056.

[10] Liistro, F., Porto, I., Angioli, P., et al.: Drug-eluting balloon in peripheral intervention for below the knee angioplasty evaluation (DEBATE-BTK): a randomized trial in diabetic patients with critical limb ischemia. Circulation, 2013, 128(6), 615-621.

[11] Mosquera Arochena, N. J.: Drug-eluting stents remain the golden standard for below-the-knee occlusive disease. J. Cardiovasc. Surg. (Torino), 2016, 57(5), 677-682.

[12] Ferraresi, R., Centola, M., Ferlini, M., et al.: Long-term outcomes after angioplasty of isolated, below-the-knee arteries in diabetic patients with critical limb ischaemia. Eur. J. Vasc. Endovasc. Surg., 2009, 37(3), 336-342.

[13] Faglia, E., Clerici, G., Caminiti, M., et al.: Mortality after major amputation in diabetic patients with critical limb ischemia who did and did not undergo previous peripheral revascularization: Data of a cohort study of 564 consecutive diabetic patients. J. Diabetes Complications, 2010, 24(4), 265-269.

[14] Faglia, E., Clerici, G., Clerissi, J., et al.: Early and five-year amputation and survival rate of diabetic patients with critical limb ischemia: Data of a cohort study of 564 patients. Eur. J. Vasc. Endovasc. Surg., 2006, 32(5), 484-490.

(Ruzsa Zoltán dr., Budapest, Gaál József út 6-8., e-mail: zruzsa25@gmail.com)

\section{Tisztelt Szerzőink, Olvasóink!}

Az Orvosi Hetilapban megjelenő/megjelent közlemények elérhetőségére több lehetőség kínálkozik.

Rendelhető különlenyomat, melynek áráról bővebben a www.akkrt.hu honlapon (Folyóirat Szerzőknek, Különlenyomat menüpont alatt) vagy Szerkesztőségünkben tájékozódhatnak.

A közlemények megvásárolhatók pdf-formátumban is, illetve igényelhető Optional Open Article (www.oopenart.com).

Adott dij ellenében az online közlemények bárki számára hozzáférhetök honlapunkon (a közlemények külön linket kapnak, így más oldalról is linkelhetővé válnak).

Bövebb információ a hirdetes@akkrt.hu címen vagy különlenyomat rendelése esetén a Szerkesztőségtöl kérhető. 